\title{
Plasma Enzymes and Electrolytes in Heterobranchus bidorsalis Treated with Cypermethrin
}

\author{
Gabriel UU ${ }^{1}$, Edori OS ${ }^{2 *}$, Egobueze EC ${ }^{2}$ \\ ${ }^{1}$ Department of Fisheries and Aquatic Environment, Rivers State University, P.M.B. 5080, Port Harcourt, Nigeria; ${ }^{2}$ Department of \\ Chemistry, Ignatius Ajuru University of Education, PMB 5047 Rumuolumeni, Port Harcourt, Nigeria
}

\begin{abstract}
Heterobranchus bidorsalis (mean total length $31.50 \pm 2.32 \mathrm{~cm} \mathrm{SD}$; mean weight $241.25 \pm 30.39 \mathrm{~g}$ SD) were exposed to graded levels solutions of cypermethrin concentrations $(0.0005,0.0075,0.010,0.125$ and $0.0150 \mathrm{ppm})$ and a control for 23 days. Plasma collected from the fish was analyzed for enzymes; aspartate transferase (AST), alanine transferase (ALT) and alkaline phosphatase (ALP) and electrolytes (sodium $\left(\mathrm{Na}^{+}\right)$, potassium $\left(\mathrm{K}^{+}\right)$and chloride $(\mathrm{Cl})$ ions. There was a non-concentration dependent increase in ALT activity above the control value of $7.00 \pm 3.83 \mathrm{IU} / \mathrm{L}$ with a peak at $0.005 \mathrm{ppm}(16.50 \pm 14 \mathrm{IU} / \mathrm{L})$, which was $135.71 \%$ above the control value. AST had variable responses with a rise in activity at 0.005 and $0.010 \mathrm{ppm}$, which were 8.26 and $5.79 \%$ above the control value of $30.25 \pm 5.38 \mathrm{IU} / \mathrm{L}$. A rise in ALP was only noted at $0.005 \mathrm{ppm}(37.75 \pm 30.40 \mathrm{IU} / \mathrm{L})$, being $115.71 \%$ above the control value. A concentrationdependent inhibition was recorded from $0.0075-0.0150 \mathrm{ppm}$ with the greatest inhibition of $88.57 \%$ at $0.0150 \mathrm{ppm}$. Sodium ion level was raised between $0.0075-0.0150 \mathrm{ppm}$ concentrations, with a peak value at $0150 \mathrm{ppm}$, which was 11.25 units (44.55\%) above the control value. A drop of 5.85 units below the control value occurred at 0.005 ppm. All the toxicant solutions caused elevation in potassium ion concentration above the value observed in the control $(4.90 \pm 1.83 \mathrm{mmol} / \mathrm{L})$. Chloride ion levels was raised at 0.005 and $0.0075 \mathrm{ppm}$, which were 7.93 and $5.05 \%$ respectively above the control value $(104.00 \pm 10.71 \mathrm{mmol} / \mathrm{L})$. Beyond this, there was a concentration-dependent decline in ionic level with the lowest level of $71.50 \pm 13.20 \mathrm{mmol} / \mathrm{L}$ at the highest concentration. The study suggests that sublethal cypermethrin levels could cause hormone and electrolyte imbalance in the exposed fish, hence caution should be applied in its application especially near water.
\end{abstract}

Keywords: Plasma; Enzymes; Electrolytes; Heterobranchus bidorsalis; Cypermethrin

\section{INTRODUCTION}

Pesticides applied on field and agricultural environments may be transported to aquatic environments through runoff, industrial releases, domestic and sewage discharges [1]. The management and control of Pest in domestic and agricultural settings is associated with pesticides application. Pests play negative role in agricultural productivity by infecting and affecting the health, well-being of plants, animals and humans who depend on them for food and other services [2]. In order to achieve optimum yield, pesticides are applied in agricultural fields to regulate, avert and alleviate pest activity $[3,4]$. Pesticides as an environmental pollutant have been documented to alter physicochemical characteristics of water, thus rendering the water quality inferior. When water quality has been compromised, it reduces the oxygen content, growth rate, nutritional value, cause mortality of aquatic organisms and general compromise in the physiological architecture of biotic organisms $[5,6]$ at the cellular and organismic levels.

Cells in organisms contain enzymes which performs different functions and therefore, when the integrity of the cell is disrupted through external interference by contaminants (pollutants), enzymes escape into the plasma/serum where their activities can be measured as a useful tool of cell integrity [7]. Other biochemical activities such as electrolytes can also be measured and in combination with enzymes can reveal the effects of xenophobic contamination in an ecosystem $[8,9]$. The response of aquatic organisms to pollution is expressed through several key biochemical activities involving enzymes which are concerned with the biotransformation system [10] and these biomarkers give early warning signs of aquatic pollution [11].

Modifications in enzyme functions is due to death of cells, increase

${ }^{*}$ Correspondence to: Edori OS, Department of Chemistry, Ignatius Ajuru University of Education, PMB 5047 Rumuolumeni, Port Harcourt, Nigeria, Tel: 08038984391; E-mail: onisogen.edori@yahoo.com

Received: January 28, 2019; Accepted: March 28, 2019; Published: April 04, 2019

Citation: Gabriel UU, Edori OS, Egobueze EC (2019) Plasma Enzymes and Electrolytes in Heterobranchus bidorsalis Treated with Cypermethrin. Biochem Anal Biochem 8:380. doi: 10.35248/2161-1009.19.8.380.

Copyright: $\odot 2019$ Gabriel UU, et al. This is an open-access article distributed under the terms of the Creative Commons Attribution License, which permits unrestricted use, distribution, and reproduction in any medium, provided the original author and source are credited. 
or decrease in enzyme production, obstruction of normal excretory route, increased cell membrane permeability or the impairment of circulation $[12,13]$. These parameters (AST, ALT, ALP, $\mathrm{Na}^{+}, \mathrm{K}^{+}$ and $\mathrm{Cl}$ ) were selected because of their importance in biochemical functions of living animals. This study therefore examined the chronic effects of cypermethrin on the plasma biochemistry (enzymes and electrolytes) of the African catfish, Heterobranchus bidorsalis)

\section{MATERIALS AND METHODS}

\section{Source, acclimation and treatment of fish}

The African catfish Heterobranchus bidorsalis (mean total length $31.50 \pm 2.32 \mathrm{~cm}$; SD mean weight, $241.25 \pm 30.39 \mathrm{~g} \mathrm{SD}$ ) bought from a privately-owned fish farm were transported in plastic containers to the Department of Chemistry Laboratory, Rivers State University, Port Harcourt, Nigeria. They were individually acclimated to laboratory conditions for seven days in $30 \mathrm{~L}$ plastic aquaria filled up to the $10 \mathrm{~L}$ mark. Each aquaria was covered with perforated lid to prevent fish from jumping out of the toxicant medium. The fish were fed once daily at a calculated on 1 percent ration based on biomass with factory prepared feeds which contains $35 \%$ crude protein within the acclimation period. Thereafter, the fishes were introduced into prepared solutions of cypermethrin $(0.005,0.0075,0.010,0.0125$ and $0.0150 \mathrm{ppm})$ and a control for 23 days. Four replicate samples were used in each of the five treatment level and control. The aquaria were washed daily to remove uneaten food and faecal matters and the solutions replaced or renewed again.

\section{Collection of blood samples}

On the $23^{\text {rd }}$ day, blood samples were collected from the fish from the kidney by inserting a $21 \mathrm{G}$ size needle behind the anal fin slightly above the urino-genital opening. The blood samples were transferred to heparinised vessels and centrifuged at $3000 \mathrm{rpm}$ for 15 mins. The plasma component of the blood was collected with a dropper or teat pipette and placed in sample bottles for enzymes and electrolytes analyses.

\section{Laboratory analysis of blood samples}

The enzymes AST and ALT were analysed based on the method of Reitman and Frankel (1957). The homogenate was prepared in phosphate buffer $0.1 \mathrm{M}, \mathrm{pH}$ of 7.4 and thoroughly mixed with $0.2 \mathrm{ml}$ of the sample and $1 \mathrm{ml}$ of substrate (aspartate and $\alpha$. ketoglutarate) for AST and (alanine and $\alpha$ - ketoglutarate) for ALT. Incubation of the substrate-aspartate- $\alpha$ - ketoglutarate mixture for AST assessment was done for a period of one hour, while that of substrate-alanine- $\alpha$ - ketoglutarate was done for 30 minutes. The reaction was stopped by the addition of $1 \mathrm{ml}$ of 2,4 - dinitrophenyl hydrazine (DNPH) solution and kept for 20 minutes at room temperature. After incubation, $1 \mathrm{ml} 0.4 \mathrm{~N} \mathrm{NaOH}$ was added and absorbance recorded at $540 \mathrm{~mm}$. Alkaline phosphatase was assayed using the method described by King and Armstrong [14], where disodium phenyl phosphate was used as the substrate. The colour developed was recorded at a spectrophotometric wavelength of 680 $\mathrm{nm}$ after 10 minutes. The electrolytes, sodium $\left(\mathrm{Na}^{+}\right)$, potassium $\left(\mathrm{K}^{+}\right)$and chloride $(\mathrm{Cl})$ levels were determined using the automatic analyzer and optimal test by means of flame photometry as described by Schales and Schales [15].

\section{Statistical treatment of data}

The data obtained from the study were subjected to analysis of variance (ANOVA), one-way classification to test if exposure the cypermethrin solutions produced any changes in the variables. Where differences existed, Duncan Multiple Range Test (DMRT) was used to separate the means [16].

\section{RESULTS}

Analysis of the plasma showed that ALT activity in the treated fish was higher than that of the control, although the change was not concentration-dependent. The value was highest at $0.005 \mathrm{ppm}$ $(16.50 \pm 14 \mathrm{IU} / \mathrm{L})$ which was $135.71 \%$ rise above the control value of $7.00 \pm 3.83 \mathrm{IU} / \mathrm{L}$ (Figure 1).

AST had variable responses with a rise in activity at 0.005 and $0.010 \mathrm{ppm}$, which were 8.26 and $5.79 \%$ above the control value of $30.25 \pm 5.38 \mathrm{IU} / \mathrm{L}$ (Figure 2).

A rise in ALP was only noted at 0.005 ppm $(37.75 \pm 30.40$ IU/L) which was $115.71 \%$ elevation above the control value. A concentration-dependent inhibition was recorded from 0.0075 . $0.0150 \mathrm{ppm}$ with the greatest inhibition of $88.57 \%$ at $0.0150 \mathrm{ppm}$ (Figure 3).

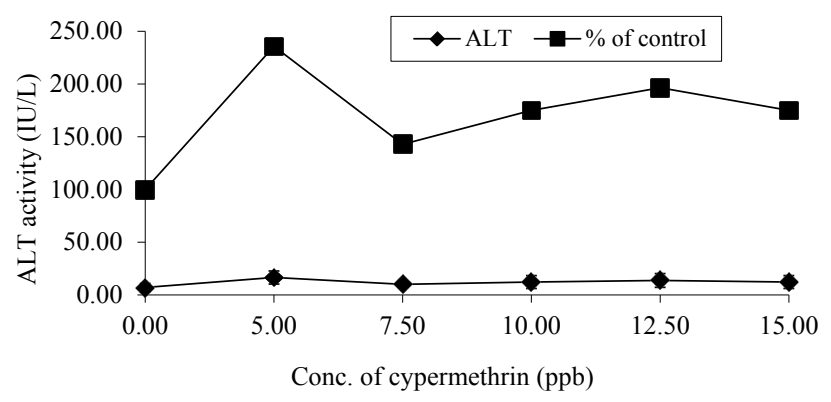

Figure 1: ALT activity in the plasma of Heterobranchus bidorsalis exposed to various concentrations of cypermethrin for 23 days.

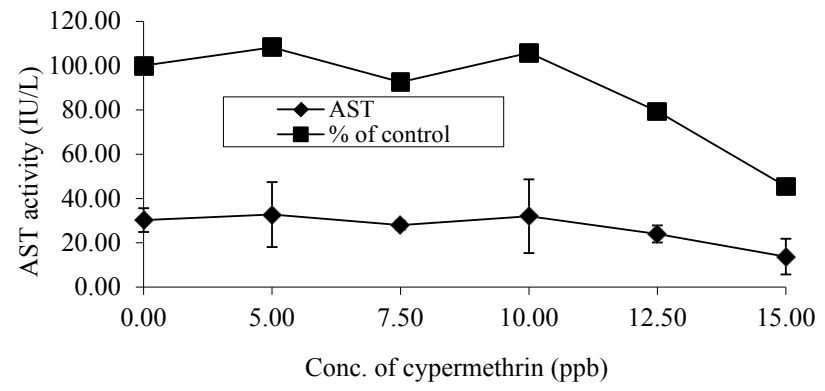

Figure 2: AST activity in the plasma of Heterobranchus bidorsalis exposed to various concentrations of cypermethrin for 23 days.

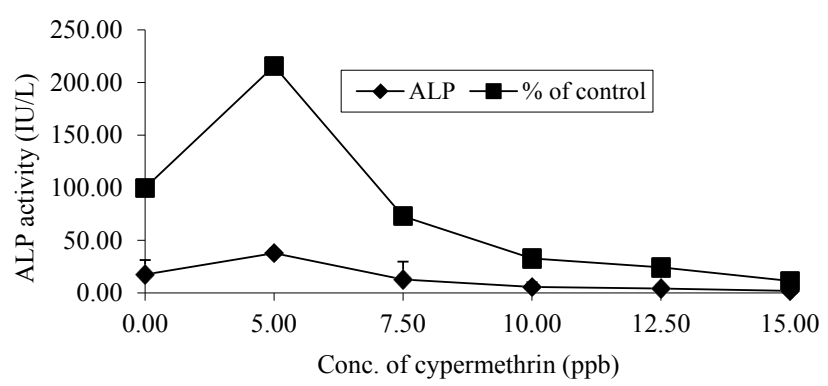

Figure 3: ALP activity in the plasma of Heterobranchus bidorsalis exposed to various concentrations of cypermethrin for 23 days. 
There was a somewhat concentration-dependent rise in sodium ion with the level raised from $0.0075-0.0150 \mathrm{ppm}$, peaking at the highest concentration, which was 11.25 units (44.55\%) above the control. A drop of 5.85 units below the control occurred at 0.005 ppm (Figure 4).

Exposed fish had elevated potassium ion concentration above the value of the control, being $4.90 \pm 1.83 \mathrm{mmol} / \mathrm{L}$ (Figure 5).

Chloride ion, had a rise at 0.005 and $0.0075 \mathrm{ppm}$, which were 7.93 and $5.05 \%$ respectively above the control value of $104.00 \pm 10.71$ $\mathrm{mmol} / \mathrm{L}$ beyond which there was a concentration-dependent decline. The lowest level of chloride ion which was $71.50 \pm 13.20 \mathrm{mmol} / \mathrm{L}$ occurred at the highest concentration (Figure 6, Tables 1 and 2).

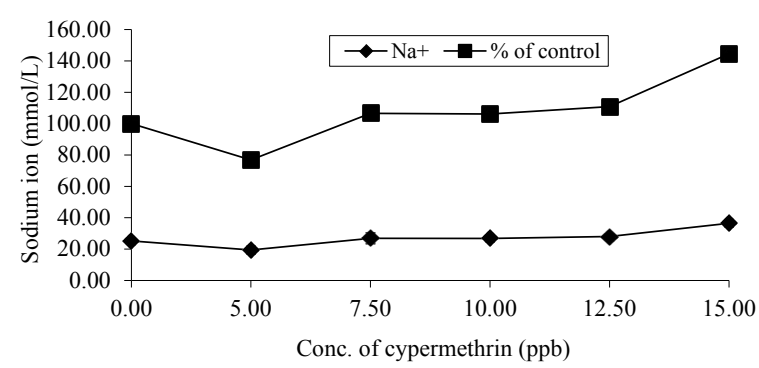

Figure 4: Levels of sodium ion in the plasma of Heterobranchus bidorsalis exposed to various concentrations of cypermethrin for 23 days.

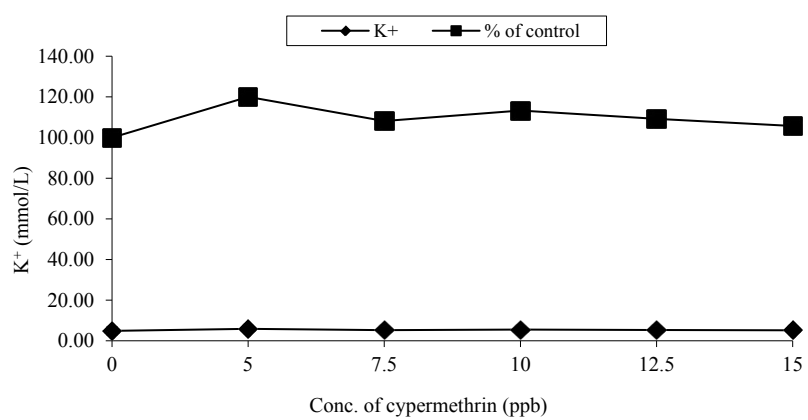

Figure 5: Levels of potassium ion in the plasma of Heterobranchus bidorsalis exposed to various concentrations of cypermethrin for 23 days.

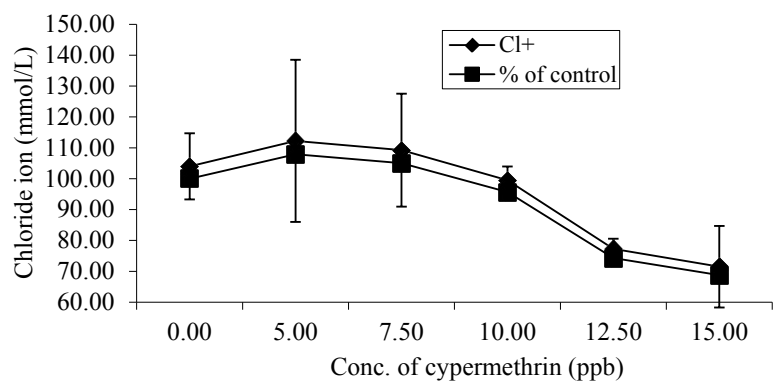

Figure 6: Levels of chloride ion in the plasma of Heterobranchus bidorsalis exposed to various concentrations of cypermethrin for 23 days.

\section{DISCUSSION}

\section{Overview}

The homeostatic mechanism of fish is continuously exposed to and influenced by changes in the aquatic ecosystem and habitat because of the close relationship between them. Hence, the biotic and abiotic factors of any ecosystem can individually or collectively (synergistically) cause stress in fish. The responses of an organism to stress have a biochemical and molecular basis which can be noticed through qualitative and quantitative changes at the subcellular and extra-cellular levels of the organism. Biochemical and molecular indicators are ideal as biological indicators in that they react quickly to changes in the ecosystem and so provide the first warning signal of these changes $[9,11]$.

\section{Enzymes}

Changes in serum/plasma AST, ALT and ALP are noted as the most sensitive biomarkers in the diagnosis of hepatic damage because they are cytoplasmic in location and are released into circulation after cellular damage [17]. They also indicate the health status of the tissue parenchyma and tissue necrosis, which is considered as the major source of their increase in the serum of animals [18]. Gabriel and George [19] observed that exposure of fish to pollutants including pesticides and herbicides might result in the stimulation or depression of enzyme activity depending on the concentration and duration of exposure as recorded in this study. Liver is the metabolic centre for the detoxification of chemicals and damage to the tissues is usually confirmed by changes in AST and ALT activities in most animals. Toxicant-induced chronic hepatic disorders and excessive steroids results in the increase of plasma ALP [13]. According to Coppo et al. [7], a large amount of ALP is found in the plasma during normal bone growth and osteopathies (bone disease).

ALP is formed principally in the liver and the bone marrow, membrane-bound closely to the biliary canaliculi and secreted into the bile. Any increase in plasma levels principally indicates a condition known as cholestasis [13].

Under stress conditions, there is the increasing demand for energy which is provided by carbohydrate, the primary source of energy in such condition [20]. Since the transaminases are affected under stress, the Kreb cycle will not function properly or normally. Any toxicant that affects the Kreb cycle (TCA cycle) alters its functions by altering the rate of electron transfer system (ETS) and oxidative phosphorylation, resulting in less ATP synthesis [20]. Decrease or increase in enzymatic activities alters tissues respiration rates and shifts the metabolism of carbohydrates towards either aerobic or anaerobic oxidation. However, in the concentrations where

Table 1: ALT, AST and ALP in the Plasma of Heterobranchus bidorsalis exposed to various concentrations of cypermethrin for 23 days.

\begin{tabular}{lcccccc}
\hline $\begin{array}{l}\text { Conc. of Cypermethrin } \\
\text { (ppm) }\end{array}$ & ALT (IU/L) & \% of Control & AST (IU/L) & \% of Control & ALP (IU/L) & $\%$ of Control \\
\hline 0.00 & $7.00 \pm 3.83^{\mathrm{b}}$ & 100.00 & $30.25 \pm 5.38^{\mathrm{a}}$ & 100.00 & $17.50 \pm 13.80^{\mathrm{b}}$ & 100.00 \\
\hline 0.005 & $16.50 \pm 6.14^{\mathrm{a}}$ & 235.71 & $32.75 \pm 14.66^{\mathrm{a}}$ & 108.26 & $37.75 \pm 3.04 \mathrm{a}$ & 215.71 \\
\hline 0.0075 & $10.00 \pm 2.31^{\mathrm{ab}}$ & 142.86 & $28.00 \pm 2.00^{\mathrm{ab}}$ & 92.56 & $12.75 \pm 17.04^{\mathrm{b}}$ & 72.86 \\
\hline 0.010 & $12.25 \pm 6.13^{\mathrm{ab}}$ & 175.00 & $32.00 \pm 16.67^{\mathrm{a}}$ & 105.79 & $5.75 \pm 4.50^{\mathrm{b}}$ & 32.86 \\
\hline 0.0125 & $13.75 \pm 6.50^{\mathrm{ab}}$ & 196.43 & $24.00 \pm 3.83^{\mathrm{ab}}$ & 79.34 & $4.25 \pm 2.87^{\mathrm{b}}$ & 24.29 \\
\hline 0.0150 & $12.25 \pm 6.13^{\mathrm{ab}}$ & 175.00 & $13.75 \pm 8.06^{\mathrm{b}}$ & 45.45 & $2.00 \pm 0.00^{\mathrm{b}}$ & 11.43 \\
\hline
\end{tabular}

Means with the same superscript in the same column are significantly different $(\mathrm{P}>0.05)$. 
Table 2: $\mathrm{Na}^{+}, \mathrm{K}^{+}$and $\mathrm{CL}^{-}$in the plasma of Heterobranchus bidorsalis exposed to various concentrations of cypermethrin for 23 days.

\begin{tabular}{lcccccc}
\hline $\begin{array}{l}\text { Conc. of Cypermethrin } \\
(\mathrm{ppm})\end{array}$ & $\mathrm{Na}^{+}(\mathrm{mmol} / \mathrm{L})$ & $\%$ of Control & $\mathrm{K}^{+}(\mathbf{m m o l} / \mathrm{L})$ & $\%$ of Control & $\mathrm{Cl}(\mathrm{mmol} / \mathrm{L})$ & $\%$ of Control \\
\hline 0.00 & $25.25 \pm 1.46^{\mathrm{a}}$ & 100.00 & $4.90 \pm 1.83^{\mathrm{a}}$ & 100.00 & $104.00 \pm 10.71^{\mathrm{a}}$ & 100.00 \\
\hline 0.005 & $19.40 \pm 2.40^{\mathrm{a}}$ & 76.83 & $5.88 \pm 0.69^{\mathrm{a}}$ & 120.00 & $112.25 \pm 26.26^{\mathrm{a}}$ & 107.93 \\
\hline 0.0075 & $26.90 \pm 3.44^{\mathrm{a}}$ & 106.53 & $5.30 \pm 0.75^{\mathrm{a}}$ & 108.16 & $109.25 \pm 18.30^{\mathrm{a}}$ & 105.05 \\
\hline 0.010 & $26.80 \pm 2.00^{\mathrm{a}}$ & 106.14 & $5.55 \pm 1.00^{\mathrm{a}}$ & 113.27 & $99.50 \pm 4.43^{\mathrm{ab}}$ & 95.67 \\
\hline 0.0125 & $28.00 \pm 1.42^{\mathrm{a}}$ & 110.89 & $5.35 \pm 0.75^{\mathrm{a}}$ & 109.18 & $77.25 \pm 3.30^{\mathrm{bc}}$ & 74.28 \\
\hline 0.0150 & $36.50 \pm 2.25^{\mathrm{a}}$ & 144.55 & $5.18 \pm 0.96^{\mathrm{a}}$ & 105.71 & $71.50 \pm 13.20^{\mathrm{c}}$ & 68.75 \\
\hline
\end{tabular}

Means with the same superscript in the same column are significantly different $(p>0.05)$.

decreased activities of AST, ALT and ALP were recorded in the plasma the structural integrity of the hepathocellular membrane may have been protected and preserved against cypermethrin assault [17].

\section{Electrolytes}

Electrolyte $\left(\mathrm{Na}^{+}, \mathrm{K}^{+}\right.$and $\left.\mathrm{Cl}\right)$ concentrations are indicative of a fish's ability to osmoregulate. Osmoregulation is usually compromised with stress, disease or gill lesions that increase gill permeability to ions (McDonald and Milligan, 1992). The higher values of blood electrolytes in the treated group may be an indication of gill and kidney damage, which may have affected the osmoregulatory ability. Change in pathology of the fish can also be due to electrolyte imbalance which in turn affects the fish physiology [21]. According to Mohanty and Mishra [22], these minerals or electrolytes have the major responsibility of maintaining osmotic pressure in the blood and proper function of all types of tissues. The presence of these activator ions, $\mathrm{Na}^{+}$and $\mathrm{K}^{+}$are essential for the proper functioning of many enzymes.

The higher levels of sodium and potassium ions in the plasma compared to the control may be attributed to kidney dysfunction, the kidney being the normal pass for sodium and potassium [18]. Sodium plays the important role of regulating the amount of fluid in the body and its transmission into and out of body cells plays a role in critical body functions. The body processes in the brain, nervous systems and muscle require electrical signals for communication [23]. Potassium in the body regulates the heartbeat and muscle functions. Its increase (hyperkaelemia) or decrease (hypokalaemia) has a profound effect on the nervous system and increases the chance of irregular heartbeats (arrhythmia) which in extreme cases can be fatal. Na-K $\mathrm{K}^{+} \mathrm{AT}$ pase and enzyme located in the cell membrane, has been implicated in the active transport of $\mathrm{Na}^{+}$ and $\mathrm{K}^{+}$across the cell membrane [24]. In the face of damage to the gill epithelia, the rate of transport may be unnecessarily increased to a level detrimental to the fish.

Decrease or increase in the chlorides may be due to induced stress from the toxicant. The balance of chloride ion is closely regulated by the body. Increase in chloride ion may be due to certain kidney disease or over reactivity of the parathyroid glands and can also arise from gill injury [25-32] or increased loss of chlorides from the gills [21]. Results from the present study, may be due to gill and kidney damage and altered enzyme activity as these were observed [24]. They suggested that such effects were an indication of impending death of the organism.

\section{CONCLUSION}

Observations from this study strongly suggest that cypermethrin may cause deleterious effects on the enzymatic and ionic balance of an important species like $H$. biodorsalis by altering the blood biochemistry of the fish. If this condition (though mild initially) is prolonged and under higher concentrations of the chemical as would be expected in field conditions, the fish may suffer severe physiological disruption which may result in death.

\section{REFERENCES}

1. Bhatnagar MC, Singh DP, Sharma I. Effect of Cypermethrin on certain blood parameters of Catla catla exposed chronically. J Ecophysiology Occupational Health. 2010;10:157-163.

2. Ojezele MO, Abatan OM. Toxicological effects of Chloropyrifos and methidathion in young chickens. African J Biochemistry Res. 2009;3:48-51.

3. Seiyaboh EI, Inyang IR, Gijo AH, Adobeni GD. Acute Toxicity of Paraquat Dichloride on Blood Plasma Indices of Clarias gariepinus. IOSR J Environmental Science, Toxicology Food Technology. 2013;7:15-17.

4. Ogamba EN, Izah SC, Nabebe G. Effects of 2,4-Dichlorophenoxyacetic acid in the electrolytes of blood, liver and muscles of Clarias gariepinus. Nigeria J Agriculture Food Environment. 2015;11:23-27.

5. Ramesh M, Saravanan M. Haematological and biochemical responses in a freshwater fish Cyprinus carpio exposed to chlorpyrifos. Int J Integrative Biology. 2008;3:80-83.

6. Inyang IR, Ekweozor IKE, Ollor A. Physiological effects of diazinon on Clarias gariepinus. Best J. 2014;11:171-176.

7. Coppo JA, Mussart NB, Fioranelli SA. Physiological variation of enzymatic activities in blood of bullfrog, Rana catesbeina. Rev Vet. 2002;13:22-27.

8. Norris DO, Camp JM, Maldonado TA, Woodling JD. Some aspects of hepatic function in feral brown trout, Salmon trutta living in maul contaminated water. Comparative Biochemistry Physiology. 2000;127:71-78.

9. Brewer SK, Little EE, Delonay AK, Beavais SL, Jones SB, Ellersieck MR. Behavioural dysfunctions correlate to altered physiology in rainbow trout (Oncorhynchus mykiss) exposed to cholinesterase inhibiting chemicals. Arch Environ Contam Toxicol. 2001;40:70-76.

10. Ozmen M, Gungordii A, Kucukbay FZ, Guler RE. Monitoring the effects of water pollution on Cyprinus carpio in Karakaya Dam Lake, Turkey. Ecotoxicology. 2005;15:157-169.

11. Strmac M, Braunbeck T. Isolated hepatocytes of rainbow trout (Oncorhynchus mykiss) liver. Comparative Biochemistry Physiology. 2000;114C:171-177.

12. Kaneko JJ. Clinical biochemistry of domestic animals, 4th edition, Academic Press, San Diego. 1989:823.

13. Okechukwu EO, Auta J. The effect of sub-lethal doses of lambda- 
cyalothrin on some biochemical characteristics of the African catfish Clarias gariepinus. J Biological Sciences. 2007;7:1473-1477.

14. King EJ, Armstrong AR. Determination of serum and bile phosphatase activity. Canadian Medical Association J. 1934;31:56-63.

15. Schales O, Schales SS. A simple and accurate method for the determination of chloride ion in biological fluid. J Biology Chemistry. 1941;140:879-884.

16. Zar HK. Statistical tools for scientific analysis. Oxford Publishers, London. 1984:319.

17. Pari L, Amali DR. Protective role of tetrahydrocurcumin (THC) an active principle of turmeric on chloroquine induced hepatoxicity in rats. J Pharm Pharm. Sci 2005;8:115-123.

18. Zaki MS, Sharaf NE, Osfor HM. Effect of vanadium toxicity on biochemical, haematological and clinicopathological changes in Clarias lazera present in the River Nile. American-Eurasian J Agric Environment 2007;2:741-745.

19. Gabriel UU, George ADI. Plasma enzymes in Clarias gariepinus exposed to chronic levels of round up (glyphosate). Environment Ecology. 2005;23:271-276.

20. Tiwari S, Singh A. Piscicidal activity of alcoholic extract of Nerium indicum leaf and their biochemical stress response on fish metabolism. Afr J Trad CAM. 2004;1:15-29.

21. Hrubec TC, Smith AS, Robertson LT. Nitrate toxicity: A potential problem of recirculating systems: A paper presented at the Department of Biomedical Science and Pathobiology, Virginia Polytechnic Institute and State University. 1996:7.

22. Mohanty BK, Mishra BN. Effect of mercurial drug (kalyoli) on albino rat blood. J Environ Biol. 1983;4:2001-2006.

23. Luskova V, Svoboda M, Kolarova J. The effects of diazinon on blood plasma biochemistry in carp (Cyprinus carpio L). Acta Vet Brno. 2002;71:117-123.

24. Rajanna B, Chapatwala KD, Vaishnav DD, Desaiah D. Changes in ATPase activity in tissues of rat fed on cadmium. J Environ Biol. 1981;2:1-9.

25. Byrne P, Speare D, Ferguson HW. Effects of a cationic detergent on the gills and blood chemistry of rainbow trout, Salmo gairdneri. Dis Aquat Org. 1989;6:185-196.

26. Biney C, Calamari D, Member TW, Naeve H, Nyakageni B, Saad $\mathrm{MAH}$. Scientific bases for pollution control in African inland waters. FAO Fisheries Report. 19871;369:9-23.

27. Hill IR. Aquatic organisms and pyrethroids. Pesticide Sci. 1989;27:429 465.

28. MacDonald DG, Milligan CL. Chemical properties of blood. In: Hoar WS, Randal DJ, Farrel AP. eds. Fish physiology. The Cardiovascular system. Academic Press, New York. 1992;12:56-135.

29. RaoJV.Effects of monocrotophos and its analysis in acetylcholinesterase activities inhibition and its pattern of recovery on euryhaline fish, Oreochromis mossambicus. Ecotoxicology Environmental Safety. 2004;59:217-222

30. Reitman S, Frankel SA. A Colorimetric method for the determination of serum aspartate and alanine transaminases. American J Clinical Pathology. 1957;28:56-63.

31. Richardson ML. Risk assessment of chemicals in the environment. U.K. RSC Publications. 1988.

32. Svensson B, Nilsson A, Johnson E, Schutz A, Akesson B, Hagmar L. Fish consumption and exposure to persistent organochlorine compounds, mercury, selenium and methylamines amongst Swedish fishermen. Scand J Work Environ Health. 1995;21:91-106. 